\title{
Academies slam NRC on nuclear safety research programme
}

\section{Washington}

THE US nuclear safety research program$m e$ is in trouble and in dire need of reform. This is the uncharacteristically scathing criticism levelled two weeks ago in a report* by the National Research Council, the research arm of the academies of science and engineering, at the safety research programme of the Nuclear Regulatory Commission (NRC).

The authors of the report say they were shocked to learn that the director of the NRC Office of Nuclear Regulatory Research at one point had not met the commission as such for nearly two years, even though the research office controls a quarter of NRC's $\$ 410$ million annual budget.

The committee also says that coordination between the research office and the Office of Nuclear Reactor Regulation is inadequate. The committee deplores the jurisdiction disputes that seem repeatedly to erupt between the two offices and the lack of a research philosophy to guide the agency's work.

Part of the trouble seems to have stemmed from budget cuts over the past five years. NRC's statutory mandate is for the safety and licensing of nuclear reactors, which means that research has always been an attractive target for budget cutters. The committee notes that the debates over the relative contributions that should be made by government and industry to nuclear safety research have not helped, but it takes no position on the proper size of NRC's safety budget, saying merely that what money there is should be spent wisely. The committee also asks for industry participation at all stages of the safety programme, asking that NRC should find the best people to carry out its research, whether they are in industry, universities or the national laboratories.

More constructively, the report from the National Research Council makes specific suggestions to make about areas of safety research that deserve attention. It says materials research will be relevant to most areas of reactor safety, and that the need for a better understanding of human factors has been underlined by the accidents at Three Mile Island and Chernobyl.

On the development of new and advanced reactor designs, the report asks that NRC should pay attention to the sometimes novel safety considerations that arise, saying that it is "poor public policy" to let advanced reactor development to proceed without regulatory guidance.

Ordinarily, as with other NRC studies, the report would have been more con-

* Revitalizing nuclear safety research, National Academy Press, Washington DC, 1986. cerned with suggestions for research. But John Ahearne, a member of the committee responsible, says that the management of research at NRC must be sorted out before a research strategy is possible.

NRC is still studying the report, but there are signs that changes are afoot. The budget request on behalf of NRC sent to Congress earlier this month asks for an extra $\$ 8$ million for research, which would take the total for next year to $\$ 119.7$ million. Management changes have been

under way since last November, when NRC announced that its research branch would be given full responsibility for generic safety issues and for probabilistic risk assessment. The research office will also concentrate on making its research relevant to regulatory needs.

It will require strong leadership from NRC if safety issues are to receive the attention they deserve, according to the committee, whose report says that strong leadership has been lacking in the past. It says, nevertheless, that "nuclear safety research is too important to be continually whipsawed and debilitated by bad management and the vicissitudes of the political process".

Joseph Palca

\section{Threat of imminent disruption in British university faculties}

London

AN unprecedented level of university disruptions with no students being awarded a degree this summer is the threat posed by UK academic staff, dissatisfied with government's intransigence and its lack of urgency in responding to a 6 per cent wage claim, now ten months old.

The action, to be led by the Association of University Teachers (AUT), which represents nearly 50,000 staff affected by the

\section{IMAGE UNAVAILABLE FOR COPYRIGHT REASONS}

Diana Warwick claims student support.

claim, will ban examination marking, prevent the award of degrees and "totally disrupt the graduate recruitment programme by industry and commerce and throw university administration into chaos".

AUT accuses the Secretary of State for Education and Science, Mr Kenneth Baker, of "cynical tardiness" in his reluctance to disclose what money has been allocated to university salaries.

The association is to conduct two national ballots, the first on a one-day strike on 5 March and the second to endorse or reject the non-marking strategy.

Diana Warwick, general secretary of AUT, claims also to have the support of the student body, although neither the teachers nor the students have officially expressed their views. She says: "If $\mathrm{Mr}$ Baker does not immediately agree to settle the salary claim for university staff he will precipitate an unprecedented level of disruption in the universities, with no student being awarded a degree this summer. Our members are always reluctant to jump to action, but now our patience has snapped. We deeply regret the possible repercussions on individual students. The National Union of Students is sympathetic to our action, and we're seeking their cooperation in breaking through this 10 month stalemate." AUT claims its members have been pushed into this action and "must now act to focus attention on the worsening plight of universities. We call on the vice-chancellors and the government to respond now."

The university staff pursued a parity claim last year, maintaining that their salaries had fallen 44 per cent behind their industrial equivalents (at the age of 32 years) and nearly 20 per cent more behind the 'high fliers'. The claim was for 6 per cent from April last year and another 18 per cent from April this year.

But the University Authorities, AUT says, refused to pay the 6 per cent and the education secretary "has reneged on his undertaking to indicate his response to the erosion and the restructuring claim".

There are no indicators that can accurately predict the support which the teachers and the students will command in any industrial confrontation. But the education secretary is not easily intimidated. $\mathrm{He}$ has already introduced legislation to abolish the body, the Burnham Committee, established under a previous administration to settle teachers' pay. After about two years of disruptive action in Britain's schools over pay and working conditions, the education secretary introduced legislation to impose a settlement on the disgruntled school teachers. Bill Johnstone 